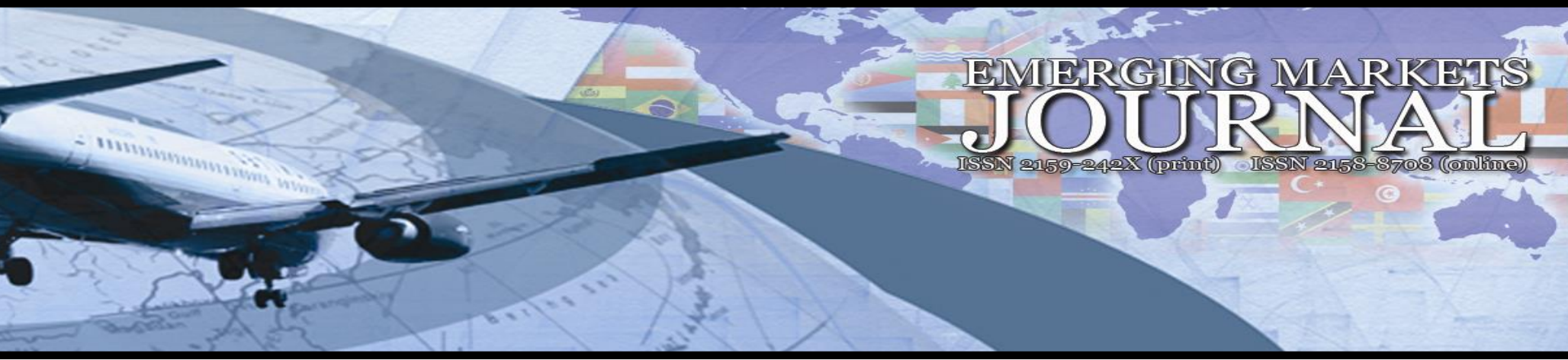

\title{
Factors Influencing the Choice of Sophisticated Management Accounting Practices - Exploratory Evidence from An Emerging Market
}

\section{Nikhil Chandra Shil}

East West University, Bangladesh | e-mail: nikhil@ewubd.edu

\section{Mahfuzul Hoque}

University of Dhaka, Bangladesh | e-mail: mahoque@du.ac.bd

\section{Mahmuda Akter}

University of Dhaka, Bangladesh | e-mail: mahmuda.akter.du@gmail.com

Volume 11 No 1 (2021) | ISSN 2158-8708 (online) ｜ DOI 10.5195/emaj.2021.211 | http://emaj.pitt.edu

\begin{abstract}
This study attempts to explore the factors that may lead to the choice behind sophisticated management accounting practices (SMAP) in an emerging economy, Bangladesh. A semi-structured questionnaire has been developed to capture the market data and different descriptive and inferential statistical tools have been used to test relevant hypotheses. The findings of the study are helpful for the management accounting practitioners, academics, and researchers to understand the current state of management accounting practices in an emerging market. In addition, the study brings an extension to existing literature by exploring potential causal relationship between sophistication in applying management accounting tools and satisfaction of management accounting practitioners. This study confirms that there is a missing link between practitioners' satisfaction and SMAP. It gives a signal to the market that the critical decision-making process is not supported by tactical exercises and market lacks professionalism greatly which may act as an obstacle to develop a competitive business environment.
\end{abstract}

Keywords: Accounting, Management Accounting Practices, Emerging Market, Exploratory Research, Sophistication

\section{(cc) $\mathrm{EY}$}

New articles in this journal are licensed under a Creative Commons Attribution 3.0 United States License.

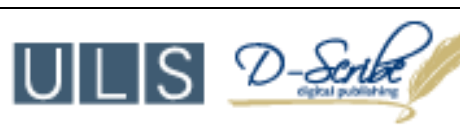

This journal is published by the University Library System of the University of Pittsburgh as part

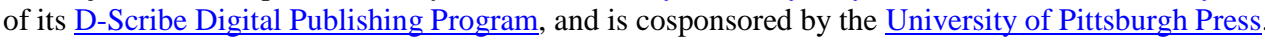




\section{Factors Influencing the Choice of Sophisticated Management Accounting Practices - Exploratory Evidence from An Emerging Market}

\author{
Nikhil Chandra Shil \\ Mahfuzul Hoque \\ Mahmuda Akter
}

\section{Introduction}

From its very inception, management accounting, as an offspring of accounting, is serving the decision-making needs of internal management. On its way, management accounting has changed every now and then as a response to changing requirements of the decision makers and thus management accounting practices do not take a particular shape. Management accounting practices combine a variety of methods, specially considered for manufacturing businesses to support the organization's infrastructure and management accounting processes (Ittner and Larcker, 2002). Companies in recent days work in a very highly competitive business environment driven by mostly unknown challenges and changes. Deregulation by encouraging private investments through privatization, borderless competition through highly decentralized corporate structure, shortening product life cycle due to rapid change in customers' tastes and requirements, serious dependency on cost effective information and production technologies, and impact of disruptive technology like data analytics, business analytics, blockchain, artificial and business intelligence, robotics, machine learning etc. have triggered firms from behind to implement sophisticated management accounting systems which may accommodate any level of difficulties with the provision of generating accurate data at desired level. Due to this revision in perception which resembles to practices, the job profile of management accountants doesn't follow traditional bean counter model (Rieg, 2018), rather replaced with business partner model, by taking a more active role in the decision making processes of organizations (Jørgensen and Messner, 2010). Research works published in leading business journals give the testimony of innovations and applications of sophisticated management accounting tools supporting this revised role of management accountants.

There was a significant downturn in research and eventual diffusion of management accounting practices after 1925 (Kaplan, 1984). Johnson and Kaplan (1987) held management accounting practitioners and researchers responsible for their unknown reluctance in bringing sophisticated tools in the field of management accounting. These criticisms acted as strong motivator which is reflected in the development of innovative tools in the field of management accounting across a range of industries within next few decades. From late 80s, different sophisticated tools have been developed in the field and highly diffused which gives management accounting practitioners a revised role from simple cost focus to forward-looking perspective (Fullerton and McWatters, 2002; Haldma and Laats, 2002). By the time, International Federation of Accountants - IFAC (1998) comes with a discussion on explaining the evolution of management accounting in a framework with four stages. Initial focus of management accountants was limited to cost determination whereby the role of management accountants was simply clerical and gradually the focus moves to the creation of values for the customers which leaves the ultimate goal of management accounting as strategic. Ittner and Larcker (2001), very rightly supported this by arguing that "companies increasingly are integrating various [innovative] practices using a comprehensive 'value-based management' ....framework".

Innovations and subsequent diffusion of innovative tools in practice requires supportive environment characterized by some sweetener. To explore motivating factors behind the choice of sophisticated tools surrounding management accounting practices, the researchers should be guided by contingency approach (Langfield-Smith, 1997; Chenhall, 2003). This approach assumes that there is no universally accepted modality of practices and every action depends on some internal and external contingent factors. This study has taken a positivistic approach in exploring the factors that may affect the choice of SMAP in an emerging economy, Bangladesh. The researchers are motivated to carry out such research from the postulate of Ittner and Larker (2002) which is "it is difficult to imagine how research in an applied discipline such as management accounting could evolve without the benefit of detailed examination of actual practice". To explore the benefit of actual practice of management accounting, this study targets to address the issue of satisfaction of management accountants, level of sophistication achieved in management accounting practices, and possible influence of practitioners' satisfaction on sophistication.

The exploration is done based on a semi-structured questionnaire designed in Likert's scale. Practicing management accountants are the targeted respondents in this study. This study puts particular focus on the identification of different contingent factors affecting the choice of management accounting tolls leading to achieve sophistication and also searches for any relationship between the sophistication of management accounting practices with the level of satisfaction of management accountants. Management accountants' contribution in establishing SMAP targeting to achieve broader corporate goals should not be undermined. Thus, the research on identifying the relationship becomes a policy issue in management accounting research. This is surely a value addition to the current state of knowledge. An earnest effort is deployed here to develop management accounting as a separate field in an emerging economy which is gradually becoming an industry led economy. Practicing management accounting embedding it with financial accounting which 
is considered as mainstream in many countries may not give the country a competitive edge. Based on the study, the researchers are convinced that the practicing field becomes matured enough to accommodate innovative tools developed so far and management accountants' satisfaction is very important to achieve sophistication.

\section{Literature Review and Hypothesis Development}

The term sophistication is referred as the application of advanced tools used to produce accurate information for internal management of corporate affairs. A handful number of researches have narrowly focused in studying the level of sophistication achieved by firms using Activity Based Costing ( $\mathrm{ABC}$ ) as a proxy to sophistication. A study (Bjornenak, 1997) on the adoption status of $\mathrm{ABC}$ used cost structure, product diversity, existing costing system and competition as prime variables where 30 companies were classified as $\mathrm{ABC}$ adopters and another 23 companies were classified into non-adopter category. Another study (Booth and Giacobbe, 1998) done on 207 Australian manufacturing firms identified size, cost structure, competition, and product diversity that influence the decision of adopting $\mathrm{ABC}$.

In a separate study done on 204 Irish manufacturing firms, Clarke et al. (1999) classified the respondents into those implementing $\mathrm{ABC}(11.76 \%)$, assessing $\mathrm{ABC}(20.59 \%)$, rejected $\mathrm{ABC}(12.75 \%)$ and having not considered $\mathrm{ABC}$ (54.90\%) which concludes that more than $50 \%$ of the firms have never considered ABC. Malmi (1999) conducted separate surveys for different industries covering a total of 490 organizations and the study resulted an adoption rate of $21 \%$ where 104 companies out of 490 had been classified as ABC adopters. The study examined few potential organizational determinants of $\mathrm{ABC}$ adoption, namely, size, competition faced, product diversity, cost structure, production type, and strategy.

Using logistic regression, Gosselin (1997) has conducted another study based on responses collected from 161 manufacturing companies from Canada to examine the effect of organizational structure and strategic posture on the adoption of activity management approaches. Using data collected from five research sites in Australia, Abernathy et al. (2001) had conducted a study which is different from others. Rather than classifying the cost systems as traditional or $\mathrm{ABC}$, they tried to classify cost systems with reference to level of sophistication. However, this study targets to explore the causal relationship between level of sophistication achieved by firms in Bangladesh and different factors driving the firms to achieve sophistication. The following factors have been identified to study their influence on the choice of SMAP.:
a) Cost composition
b) Competition
c) Product diversity
d) Size
e) Use of information technology
f) Decision-making usefulness
g) Maturity
h) Satisfaction

\section{Cost Composition}

One of the important reasons of moving towards sophisticated system is to ensure accuracy in product costing in firms where cost composition is critical, means overhead cost as a percentage of total cost of production is significant. Both the traditional and sophisticated product costing systems assign direct costs to costs object through directly tracing the cost with cost objects. However, simplistic costing system fails to assign indirect costs to cost objects accurately generating different level of distortion in product costing. One of the prime objectives of sophistication in product costing is to translate indirect costs into direct conceptually so that the assignment of indirect costs to ultimate cost object becomes meaningful. Johnson and Kaplan (1987) rightly mentioned that the modification in costing systems is caused by the dramatic change in cost structures over several decades.

In recent years, direct labor hour based unsophisticated systems fall into serious criticism for reporting distorted product cost data due to the trend of increased overhead cost as a percentage of total costs (Cooper, 1988). Brierley et al. (2001) also confirmed a potential change in cost structure based on surveys conducted in firms from Europe and United States of America (USA). They concluded that direct material cost is comparatively higher than indirect costs; however, direct labor cost comprises a very small fraction of total costs. The choice of sophisticated system is necessarily guided by the composition in cost structure. The significance of overhead costs in the overall cost structure is an important parameter behind the selection of sophisticated methods for allocating indirect costs to cost objects (Brierley et al., 2001). As traditional systems are responsible for distorting product cost through wrongly allocating indirect costs to cost objects, Cooper and Kaplan (1992) have suggested using ABC systems by organizations with high indirect costs. Organizations with low indirect cost composition, however, they have supported using traditional unsophisticated systems. Thus, the literature supports to implement sophisticated systems to ensure accuracy in product costing for those firms showing significant percentage of indirect costs in total cost structure. Based on the above literature, it is confirmed that the design of sophisticated costing system depends on the significance of indirect costs in respective cost structures of firms. Based on the discussion above, the following hypothesis has been formed for investigation:

H1: There is a positive and significant relationship between the percentage of indirect costs and the level of the sophistication of the costing system.

\section{Competition}

Competition is the most important external factor for stimulating managers to begin to work on a new cost system (Bruns, 1987). Companies operating in competitive environments should be encouraged to change their control systems, because proper costing systems and appropriate performance monitoring are fundamental to survival (Libby and Waterhouse, 1996). Market competition generates turbulence, stress, risk, and uncertainty for enterprises, so that they continuously 
adjust their control system in response to the threats and opportunities in the competitive environment (Mia and Clarke, 1999).

The choice of employing relatively sophisticated cost and management accounting systems is caused by the intensity of competition faced by companies in a particular market environment. Mia and Clarke (1999) tested the relationship between the intensity of market competition and the use of information by managers. They concluded that the increase in the intensity of competition in the market is associated with the increased managerial use of management accounting information. Libby and Waterhouse (1996) also found a positive relationship between intensity of competition and the design and use of management accounting systems. Similarly, Al-Omiri and Drury (2007) found a positive association between the intensity of competition and the sophistication level of the cost system. Researchers have also argued that firms operating in a more competitive environment are under the pressure of assigning costs accurately to products, services and customers than others operating in a less competitive environment. This pressure leads them to install more sophisticated cost systems. Otherwise, there is a high chance that competitors will take advantages of any errors made in decision making which is caused by inaccurate cost information generated through traditional systems. In line with the discussion above, this study has made the following hypothesis for investigation:

$\mathrm{H} 2$ : There is a positive and significant relationship between competition and the level of the sophistication of the costing system.

\section{Product Diversity}

Product diversity covers different variations in the offerings by a firm which may include support, process and volume diversity. Support diversity captures the pattern of services that each product receives from different service rendering units in organizations. Process diversity identifies all the required processes relating to design, manufacture and distribution of products with a particular focus of understanding the pattern of resources consumed by different processes. Volume diversity arises from the manufacturing variations caused by differences in production in terms of volumes and batches. A sophisticated costing system is demanded seriously to neutralize the impact of all these diversities on costing.

Researchers, based on studies, have argued that one of the important factors for reporting distorted product costs by traditional costing systems is product diversity (Cooper, 1988 and Estrin et al., 1994). This product diversity becomes a serious concern when the resources consumed by different products vary significantly. To address these wide variations in resource consumption by different products, the application of more sophisticated costing systems is warranted. In absence of sophisticated costing systems, significantly distorted product costs are likely to be reported due to the inability of simplistic costing systems to adjust the resource consumption pattern by different cost objects.

It is commonly accepted and understood that the type of costing system used and the underlying production process are somehow related (Malmi, 1999).
The choice of costing system should logically be guided by the complexity of the production process. The more complex production process demands sophisticated costing system to capacitate the system for handling extra difficulty. Product diversity, sometimes, gives proxy to the prevalence of complexity of production process. As the products are getting more complex in terms of production process, they require more activities to manufacture them. As a result, it demands sophisticated cost accounting systems to measure the resource consumption of different products differently. The foregoing discussion concludes that sophisticated system is important when firms have greater product diversity and thus, the following hypothesis is hereby formed for investigation:

H3: There is a positive and significant relationship between product diversity and the level of the sophistication of the costing system.

Size

Organizational size, measured in sales, assets or number of employees, have found positively related with the initiative of adopting sophisticated management accounting systems. Research has shown that larger firms have more SMAP as compared with smaller firms. In India, organizational size was found to be an important factor in adopting advanced management accounting practices (Joshi, 2001). In the UK, Al-Omiri and Drury (2007) also found a positive relationship between the organization's size and the level of cost system sophistication. Study done by Albu and Albu (2012) also revealed that size is one of the most important factors for the adoption and use of management accounting techniques.

Size is an important organizational context variable and it can affect the way in which organizations design and use management systems. The size of firm has been shown to affect the design and scope of management accounting practices (Abdel-Kader and Luther, 2008; Albu and Albu, 2012). Abdel-Kader and Luther (2008) found that large enterprises in the UK food and drink industry adopted more SMAP than small ones. Behind the choice of more SMAP by larger firms, a possible reason may be that the larger organizations have greater resources to afford adopting sophisticated systems as compared to their smaller counterparts (Haldma and Laats, 2002; Al-Omiri and Drury, 2007; and AbdelKader and Luther, 2008). To confirm a similar relationship, this study also assumes that size is an important factor behind the choice of sophisticated system and formed the following hypothesis for investigation:

H4: There is a positive and significant relationship between size and the level of the sophistication of the costing system.

\section{Use of Information Technology}

Management accounting system should be compatible with providing critical information at the demand of the decision makers. This information is mostly intuitive in nature and very much situational which is not known previously. This information is very 
costly due to the decision-making usefulness which will provide competitive edge in the market. Thus, information technology used in processing information should be highly integrative, real-time and should allow query based solution. In this era of $4^{\text {th }}$ industrial revolution, technological innovation has changed the language of business data analysis. Management accounting systems have undergone significant changes due to the use of blockchain, machine learning, data analytics, business intelligence and other advanced technologies. Based on a field study covering management accounting and control systems in South Africa, the researchers found that one of the main motivators of change in management accounting and control systems is changes in technology, in particular information systems (Waweru et al., 2004). Szychta (2002) also agreed that technology is one of driving forces behind the shift in use of management accounting practices in Poland. Sophisticated system demands such information technology which is intelligent enough to respond to the needs of the decision maker instantly. Dependence on information technology in a simplistic system environment is not that much critical. Even a simplistic system cannot provide required information real time rather defers it with reference to some future time period. This is due to low investment on information technology, skilled manpower and other infrastructure. To understand the influence of information technology on the choice of sophisticated system, this study investigated the following hypothesis:

H5: There is a positive and significant relationship between use of information technology and the level of the sophistication of the costing system.

\section{Decision-Making Usefulness}

Business decision making process is essentially being substantiated by cost and other relevant information. Product costing system is the center of generating relevant cost data in most of the manufacturing firms. A wrong product costing system brings data sterility through under-costing or overcosting whereby subsidizing a group of customers for another. The scope of product costing system has been expanded considerably in recent times to generate additional information having decision making usefulness. Based on relevant information, firms may take only profitable ventures and deal with unprofitable ventures differently. Cost information is important to take different operational and strategic decisions like separation of profitable and unprofitable activities, decision on outsourcing and redesign, cost reduction initiatives, pattern of resource consumptions and disparity among the products, product and service mix decisions etc. In summary, a drive to achieve accuracy in product costing guarantees to provide a great deal of information to help the firms taking accurate decision making. Wrong decision based on irrelevant and inaccurate data may lead not only to face the litigation but also being unfit in the marketplace to survive and grow. The discussion supports the necessity of accurate cost information for product costing and pricing decisions which necessitate sophisticated system in operation. This study, thus, takes the following hypothesis for investigation:
H6: There is a positive and significant relationship between decision making usefulness and the level of the sophistication of the costing system.

\section{Maturity}

Sophisticated costing system demands different firm specific parameters which are usually related to number of years the firm is under operation. Liability of newness gives us an important understanding about the likelihood of survival where younger firms runs the risk of being non-existed than their older counterparts with the meaning that age is associated with the likelihood of survival (Hannan and Freeman, 1989). And sophisticated costing system supplements the survival issues of firms through providing valuable information timely. IFAC (1998) has developed the framework explaining the evolution of management accounting practices where the level of sophistication is defined with reference to a particular timeline. Learning accrues from experiences through ages which are very much similar to the process how learning curve operates. This learning about management can be easily converted into improved Management Control Systems (MCS) even though the company is not growing. Age may be related to the emergence of management process if MCS facilitate (Davila, 2005). This discussion eventually acknowledges that the maturity of firms is a very important factor to design and use sophisticated system to remain relevant and competitive. To explore this reality, the following hypothesis is formed for investigation:

\section{H7: There is a positive and significant relationship between maturity and the level of the sophistication of the costing system.}

\section{Satisfaction}

The study will enrich the scope of management accounting research by bringing management accountants' satisfaction in explaining sophistication of management accounting practices. Current literature is limited to the study of level of sophistication with the identification of contextual factors explaining the level of sophistication without considering any impact of practitioners' satisfaction on it. The study plans to investigate the potential existence of a relationship between management accountants' satisfaction and the level of sophistication in management accounting practices. The establishment of this relationship is perceived to be important for the empowerment of management accountants and diffusion of sophisticated management accounting techniques through continuous change and innovations. The following hypothesis is taken for investigation:

H8: There is a positive and significant relationship between management accountants' satisfaction and the level of the sophistication of the costing system.

\section{Research Methodology}

This study applied quantitative research methodology predominantly where main research instrument was a semi-structured questionnaire. Based on 
literature review and research objectives, a draft questionnaire was developed. Using snow-ball sampling method, the draft questionnaire was pre-tested where a total of 27 respondents participated until the saturation point was reached. Then the draft questionnaire was finalized with little modification to draft questionnaire based on the result of pre-testing and the questionnaire was finalized before commissioning the final study.

To bring more objectivity in research methodology, a sample frame is thought of the manufacturing companies where professional management accountants are working. This is done through the scrutiny of membership directory of the Institute of Cost and Management Accountants of Bangladesh (ICMAB) for the year 2017. Such scrutiny results 200 companies where the members of ICMAB were working. The study doesn't consider any service industry and companies operating outside Dhaka, the capital city of Bangladesh. Out of the 200 companies, management accountants from 47 companies expressed their reluctance to participate in the survey. Other 153 companies are considered as the sample for the study. However, questionnaires are not received from 28 companies though they have been given remainder in time and 12 of the received questionnaires are rejected due to the missing data. Finally, a total of 113 questionnaires are used for data analysis based on which the research draws major conclusions.

\section{Constructs}

This study uses different constructs to test relevant hypothesis. These constructs are given below with definitions and related scales:
Table 1: Constructs used in the Study

\begin{tabular}{|c|c|c|}
\hline Constructs & Definitions & Scales \\
\hline Cost composition & $\begin{array}{l}\text { Overhead cost } \\
\text { as a percentage } \\
\text { of total cost of } \\
\text { production }\end{array}$ & ratio \\
\hline Competition & $\begin{array}{l}\text { Composite scale } \\
\text { considering } \\
\text { price, product } \\
\text { and marketing } \\
\text { competition }\end{array}$ & $\begin{array}{l}\text { 7-point } \\
\text { Likert }\end{array}$ \\
\hline Product diversity & $\begin{array}{l}\text { Considers } \\
\text { physical size, } \\
\text { complexity and } \\
\text { batch size of } \\
\text { production }\end{array}$ & $\begin{array}{l}\text { 5-point } \\
\text { Likert }\end{array}$ \\
\hline Size & $\begin{array}{l}\text { Number } \\
\text { employees }\end{array}$ & ratio \\
\hline $\begin{array}{l}\text { Use of information } \\
\text { technology }\end{array}$ & $\begin{array}{l}\text { Composite scale } \\
\text { covering the use } \\
\text { of IT across } 4 \\
\text { areas }\end{array}$ & $\begin{array}{l}\text { 7-point } \\
\text { Likert }\end{array}$ \\
\hline $\begin{array}{l}\text { Decision-making } \\
\text { usefulness }\end{array}$ & $\begin{array}{l}\text { Composite scale } \\
\text { covering the } \\
\text { usefulness of } \\
\text { decision making } \\
\text { in } 4 \text { areas }\end{array}$ & $\begin{array}{l}\text { 7-point } \\
\text { Likert }\end{array}$ \\
\hline Maturity & In terms of age & ratio \\
\hline Satisfaction & $\begin{array}{l}\text { Covering the } \\
\text { dimensions of } \\
\text { satisfaction }\end{array}$ & $\begin{array}{l}\text { 7-point } \\
\text { Likert }\end{array}$ \\
\hline Sophistication & $\begin{array}{l}\text { Using multi- } \\
\text { criteria decision } \\
\text { making } \\
(\mathrm{MCDM}) \\
\text { techniques } \\
\text { across four } \\
\text { variables }\end{array}$ & ratio \\
\hline
\end{tabular}

Source: Authors' own compilation 


\section{Conceptual Framework}

Considering the major theme of the study, constructs considered and relationship studied, a conceptual framework of the study is presented below:

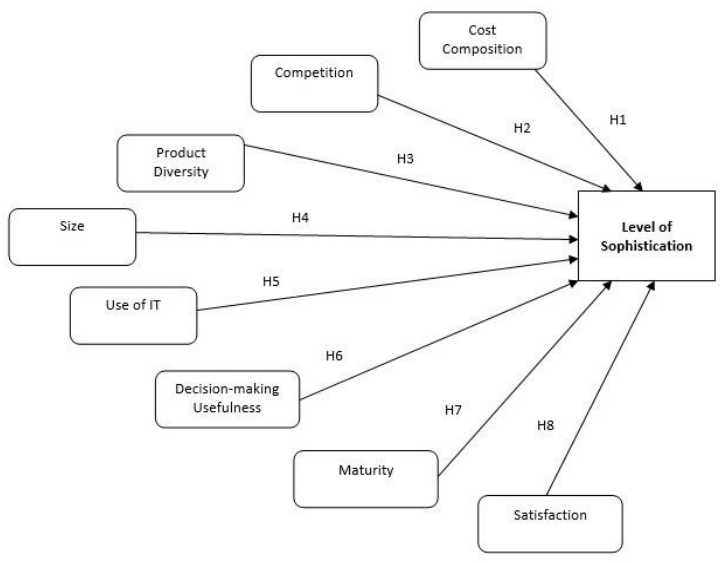

Figure 1: Conceptual Framework of the Study

Source: Authors' own compilation

\section{Measurements}

In this study cost composition covers the significance of indirect costs as compared with total costs in percentage for the respondents' firm. To understand competition faced by the responding firm, three questions were asked covering product, pricing and marketing areas. Respondents were asked to choose values in a 7point Likert scale where 1 refers to 'extremely disagree' and 7 refers to 'strongly agree'. In empirical studies, the perceived intensity of competition has been measured differently in different studies. Several studies have been based on Khandwalla's (1977) model (Libby and Waterhouse, 1996; Williams and Seaman, 2001; Hoque, 2008) which consists of five questions rating intensive competition for raw material, technical personnel, selling and distribution, quality and the variety of products and price. On the other hand, Mia and Clarke (1999) measured the intensity of competition by only one Likerttype scale question but taking into account all factors, including number of major competitors, frequency of technological change in the industry, frequency of new product introduction, extent of price manipulations, package deals for customers, access to marketing channels and change in government regulation or policy.

Product diversity follows a composite scale covering physical size, complexity and batch size. A 5point Likert scale is used to capture the feedback where 1 refers to 'not at all' and 5 refers to 'to a very great extent'. Size of firm is typically measured by the number of employees working for an organization or its total assets or its total sales. This study uses number of employees to measure size. To measure use of information technology and decision-making usefulness, a composite scale is designed on 7-point Likert scale where 1 is used to mean 'strongly disagree' and 7 is used to mean 'strongly agree'. Maturity is measured in terms of the age of the company; however, different dimensions of satisfaction is measured using a 7-point
Likert scale anchoring 1 for 'very dissatisfied' and 7 for 'very satisfied'.

To measure the value of sophistication, a weighted multi-criteria method is applied. Four different parameters used as criteria in measuring sophistication are Pool-Driver Quantitative, Pool-Driver Qualitative, Education and Advanced Management Accounting Techniques Adoption with their respective weights and sub-weights. The methodology results a value between 1 and 100 for every firms where a value close to 100 means sophisticated system and values close to 1 means unsophisticated system. For the application of logistic regression, the dependent variable sophistication is converted to categorical variables as follows:

Unsophisticated System $=$ Value between 1 and 50 Sophisticated System $=$ Value between 51 and 100

Statistical Tools Used

Different descriptive and inferential statistical tools (e.g., regression analysis) are used to test the hypotheses formulated in the study. A correlation between and among the variables is shown for explaining the suitability of each construct in regression analysis. A multiple regression is run to understand the relationship of each construct with the level of sophistication. To run logistic regression, level of sophistication has been made a categorical variable. Finally, in a separate regression analysis, the study looks for any relationship between satisfaction and sophistication.

\section{Analysis and Findings}

This section presents analysis and findings of the study in different sub-sections. Initially it begins with explaining the respondents and corporate profile of the study using descriptive form of analysis. Then, all the hypotheses formed in literature review section have been tested using regression analysis. Findings of the analysis are presented at the end.

\section{Respondents' and Corporate Profile}

A total of 113 respondents participated in this study. These participants vary in terms of their educational background, years of experience, turnover intention, no of jobs and their position in organizational chain of command. Around $41 \%$ of the respondents are professional accountants, while other $50 \%$ have master's degree. In terms of years of experience, around $78 \%$ of the respondents have more than 5 years of experience. A good percentage of the employees seem to be happy with their job which is reflected in less percentage (18\%) of respondents having an intension of switching the job. Respondents are not so much job hopper where only few respondents $(6 \%)$ have switched above 5 jobs where around $78 \%$ of the respondents hold positions in either mid level or top level management.

Like the number of the respondents, a total of 113 firms have participated in this study as 1 respondent has responded from each firm. Questionnaire captures the profile of responding firms in terms of total number of years in operation, number of employees, annual turnover and net assets. Around 20 firms out of 113 have less than 10 years of operation, and $58 \%$ of the firms having less than 1,000 of employees. In terms of 
turnover, $68 \%$ of the firms reports more than Bangladesh Taka (BDT) 100 million while around $78 \%$ of responding firms have more than BDT 100 million invested in net assets.

\section{Correlation Coefficient}

To measure the strength of the relationship between the relative movements of each pair of variables, a correlation matrix is derived. It shows the relationship between alternative measures of cost system sophistication and factors affecting sophistication. Use of information technology and competition are positively correlated $(\mathrm{p}<0.01)$ with decision making usefulness. Competition is also positively correlated $(p<0.01)$ with decision making usefulness. Size is positively correlated $(\mathrm{p}<0.01)$ with sophistication based on 100-point scale whereas it is negatively correlated $(\mathrm{p}<0.05)$ with sophistication classified by two categories. On the other hand, maturity is positively correlated $(p<0.05)$ with size.

\section{Table 2: Spearman Correlation Coefficients}

\begin{tabular}{|l|r|r|r|r|r|r|r|l|}
\hline & 1 & 2 & 3 & 4 & 5 & 6 & 7 & 8 \\
\hline 1. Sophistication & & & & & & & & \\
\hline $\begin{array}{l}\text { 2.Sophistication } \\
\text { (2 Categories) }\end{array}$ & $-.739^{* *}$ & & & & & & & \\
\hline 3. Cost Composition & -.081 & .084 & & & & & & \\
\hline 4. Product Diversity & .125 & -.023 & -.033 & & & & & \\
\hline $\begin{array}{l}\text { 5.Decision-making } \\
\text { Usefulness }\end{array}$ & .071 & .046 & .042 & .161 & & & & \\
\hline $\begin{array}{l}\text { 6. Use of Information } \\
\text { Technologies (IT) }\end{array}$ & .089 & -.079 & .155 & -.009 & $.573^{* *}$ & & & \\
\hline 7. Competition & .000 & .119 & .129 & -.046 & $.548^{* *}$ & $.292^{* *}$ & & \\
\hline 8. Size & $.341^{* *}$ & $-.219^{*}$ & -.035 & .164 & .036 & .132 & -.049 & \\
\hline 9. Maturity & .160 & -.116 & .036 & -.068 & .128 & .087 & .024 & $.212^{*}$ \\
\hline
\end{tabular}

** Correlation is significant at the 0.01 level (2-tailed)

* Correlation is significant at the 0.05 level (2-tailed)

Source: SPSS Output

\section{Multiple Regression Analysis}

This study uses regression analysis predominantly as a tool for drawing inferences. Correlation coefficients as presented above confirm the use of every construct as a separate one. To test the reliability of scales used, Cronbach alpha value is calculated and for all the constructs alpha results exceeded 0.70 which confirms the reliability of scales. Based on the research objectives and conceptual framework, a regression model is developed as below:

$\mathrm{Y}=\mathrm{b}_{1}+\mathrm{b}_{2}$ COSTCOMP $+\mathrm{b}_{3}$ PRODVA $+\mathrm{b}_{4}$ USECOST + $\mathrm{b}_{5} \mathrm{USEINFOTECH}+\mathrm{b}_{6} \mathrm{COMP}+\mathrm{b}_{7} \mathrm{SIZE}+\mathrm{b}_{8} \mathrm{AGE}+\mathrm{e}$

Where:

$\begin{array}{ll}\text { Y } & =\begin{array}{l}\text { Sophistication based on } 100 \\ \text { point scale }\end{array} \\ \text { COSTCOMP } & =\text { Cost composition } \\ \text { PRODVA } & =\text { Product diversity } \\ \text { USECOST } & =\text { Decision-making usefulness } \\ \text { USEINFOTECH } & =\text { Use of information technology }\end{array}$

COMP $=$ Competition

SIZE $=$ Size

AGE = Maturity

In this regression model, sophistication (y) is used as a dependent variable with other seven constructs which may influence achieving sophistication in cost system design and use. As satisfaction is considered separately, this model doesn't consider satisfaction. ANOVA and model summary of the regression analysis explains the model fitness, significance and explanatory power of all the constructs together on the dependent variable of the model. It results a value of .345 for $\mathrm{R}$ which is the multiple correlation coefficient defining the correlation between the observed values of the response variable and the values predicted by the model. Its square $\left(\mathrm{R}^{2}\right)$ gives the proportion of the variability of the response variable accounted for by the explanatory variables. A value of .345 for $\mathrm{R}$ indicates a weak correlation and .119 for $\mathrm{R}^{2}$ means only $11.9 \%$ of the change in sophistication is accounted for by the explanatory variables collectively. However, the model becomes statistically significant $(F(7,105)=2.030, p<$ 0.05 ), and so concludes that at least one of the explanatory variables is related to the level of sophistication.

Table 3 below extends regression analysis with the beta coefficients of each construct and multicollinearity diagnostics. We can easily predict the influence of each explanatory variable on the response variable.

Table 3: Regression Analysis - Coefficients

\begin{tabular}{l|rr|r|r|r|rr|}
\hline & \multicolumn{2}{|c|}{$\begin{array}{c}\text { Unstandardized } \\
\text { Coefficients }\end{array}$} & $\begin{array}{c}\text { Standardized } \\
\text { Coefficients }\end{array}$ & \multirow{2}{*}{$\mathrm{t}$} & \multirow{2}{*}{ Sig. } & \multicolumn{2}{|c|}{$\begin{array}{c}\text { Collinearity } \\
\text { Statistics }\end{array}$} \\
\cline { 2 - 3 } & \multicolumn{1}{|c|}{$\mathrm{B}$} & Std. Error & (Beta) & & & Tolerance & VIF \\
\hline (Constant) & 32.821 & 5.892 & & 5.571 & .000 & & \\
Cost Composition & -.060 & .083 & -.068 & -.718 & .474 & .948 & 1.055 \\
Production Diversity & 1.229 & .854 & .137 & 1.438 & .153 & .922 & 1.084 \\
Decision-making use. & -.289 & 1.400 & -.033 & -.206 & .837 & .321 & 2.116 \\
Use of IT & .475 & 1.131 & .053 & .420 & .675 & .525 & 1.903 \\
Competition & .193 & 1.108 & .024 & .174 & .862 & .449 & 2.228 \\
Size & $8.012 \mathrm{E}-5$ & .000 & .027 & .285 & .776 & .928 & 1.078 \\
Maturity & .207 & .061 & .325 & 3.372 & .001 & .903 & 1.107 \\
\hline
\end{tabular}

Source: SPSS Output

As per the coefficients presented above, only one construct (maturity) out of seven becomes statistically significant $(p<0.05)$. The beta coefficient becomes .325 (standardized) which means it has a positive relationship with sophistication and around $32 \%$ of change in sophistication is explained by age of the firm. Product diversity, Use of information technology, competition and size show positively related with sophistication, however, not significant. On the other hand, cost composition and decision-making usefulness result negative relationship with sophistication which is also not significant.

Regression becomes impossible in case of existence of multicollinearity and thus, it is important to confirm that the independent variables are not related to 
each other. Regression analysis results two statistics, e.g., tolerance and VIF, to report the status of multicollinearity. As per the values resulted in above table for tolerance and VIF, there exists no multicollinearity which may be a concern for regression analysis.

\section{Binary Logistic Regression}

To use binary logistic regression as an extension to the analysis done above, the dependent variable (level of sophistication) of the model has been made binary. As mentioned in methodology section, firms having a value up to 50 in a 100 point scale have been considered as 'no' means not using sophisticated system and firms having a value more than 50 have been considered as 'yes' means using sophisticated system. The model like multiple regression model tests the influence of all the seven constructs on achieving the level of sophistication of firms. As per the result of the test, the value of Chi-Square becomes 10.022 on $7 \mathrm{df}$ which is not significant. It gives an indication that the variables added to the model don't impact the dependant variable significantly. Other results of logistic regression analysis are presented below:

\section{Table 4: Logistic Regression Analysis}

\begin{tabular}{|l|r|r|r|r|r|}
\hline & B & S.E. & Wald & Sig. & Exp(B) \\
\hline Cost Composition & .000 & .019 & .001 & .975 & .999 \\
\hline Product Diversity & .162 & .201 & .651 & .420 & 1.176 \\
\hline $\begin{array}{l}\text { Decision-making } \\
\text { Usefulness }\end{array}$ & -.196 & .303 & .419 & .517 & .822 \\
\hline $\begin{array}{l}\text { Use of Information } \\
\text { Technology }\end{array}$ & .195 & .259 & .564 & .453 & 1.215 \\
\hline Competition & -.106 & .238 & .199 & .656 & .899 \\
\hline Size & .000 & .000 & .174 & .677 & 1.000 \\
\hline Maturity & .038 & .014 & 7.234 & .007 & 1.038 \\
\hline Constant & -1.829 & 1.263 & 2.098 & .148 & .161 \\
\hline Chi-Square & 10.022 & & & & \\
\hline $\begin{array}{l}\text { Cox \& Snell R } \\
\text { Square }\end{array}$ & .085 & & & & \\
\hline Nagelkerke R Square & .127 & & & & \\
\hline -2 Log likelihood & 114.245 & & & & \\
\hline
\end{tabular}

\section{Source: SPSS Output}

The predictability of the model is very poor which is reflected in larger value of -2 Log likelihood statistics. Cox \& Snell R Square and Nagelkerke R Square measure the proportion of variance explained by the predictor variables which vary from $8.5 \%$ to $12.7 \%$ as given in Table 9 above. An interesting issue is that the construct 'maturity' becomes statistically significant like before. Cost composition and size result zero betas showing no influence of sophistication whereas decisionmaking usefulness and competition result a negative relationship with the level of sophistication. Using the values of logistic regression analysis, the Logit model could be written as:
Logit $(\mathrm{p})=\ln \left(\frac{p}{1-p}\right)=-1.829+.000($ COSTCOMP $)+$

$.162(\mathrm{PRODVA})$
$.195(\mathrm{USEINFOTECH})$
$.038(\mathrm{AGE})$

This model could be used to find out the probability of being sophisticated system by a firm with respective values for all the constructs in the model. A firm with $50 \%$ manufacturing overhead costs, degree of product diversity 2 , level of use of cost data 5.75, level of use of information technology 6 , level of competition 4 , number of employees 300 and years in operation 21, the probability can be computed by using the equation as below:

Logit $(\mathrm{p})=-1.829+.000(50 \%)+.162(2)-.196(5.75)+$ $.195(6)-.106(4)+.000(300)+.038(21)$ $=-1.088$

$\operatorname{Exp}^{-1.088}=0.33688$

Let us transform it to obtain the probability as $\frac{\exp ^{-1.088}}{1+\exp ^{-1.088}}=0.25199$

One of the important uses of logit value is the computation of odds ratio where odds are computed from two respondents to get a comparative status between, say, two competing firms. For example, let us consider the steps as used above to calculate the odds for a firm with different values for each construct as given in following equation:

Logit $(\mathrm{p})=-1.829+.000(10 \%)+.162(3)-.196(5.75)+$ $.195(6)-.106(4.333)+.000(18000)+.038(17)=$ $-1.1313$

$\operatorname{Exp}^{-1.1313}=0.32261$

Let us transform it to obtain the probability as $\frac{\exp ^{-1.1313}}{1+\exp ^{-1.1313}}=0.2439$

Thus, the odd ratio will be $\mathrm{Odd}_{1} / \mathrm{Odd}_{2}$, i.e. $0.25199 / 0.2439=103.32$. It means the first firm enjoys 103.32 times higher probability of attaining sophistication as compared with the second firm.

\section{Satisfaction and Sophistication}

Based on the conceptual model, a separate regression analysis is done to explore any relationship between satisfaction and sophistication. The model becomes statistically insignificant and the values for $\mathrm{R}$ and $\mathrm{R}^{2}$ result .139 and .019 respectively with a very low explanatory power. 
Table 5: Regression Results (Sophistication and Satisfaction)

\begin{tabular}{|c|c|c|c|c|c|c|c|}
\hline & \multicolumn{2}{|c|}{$\begin{array}{l}\text { Unstandardized } \\
\text { Coefficients }\end{array}$} & \multirow{2}{*}{$\begin{array}{c}\text { Standardized } \\
\text { Coefficients } \\
\text { (Beta) }\end{array}$} & \multirow[t]{2}{*}{$t$} & \multirow[t]{2}{*}{ Sig. } & \multicolumn{2}{|c|}{$\begin{array}{l}\text { Collinearity } \\
\text { Statistics }\end{array}$} \\
\hline & $B$ & Std. Error & & & & Tolerance & VIF \\
\hline (Constant) & 32.976 & 6.234 & & 5.289 & .000 & & \\
\hline Overall Satisfaction & 1.118 & 1.686 & .100 & .663 & .509 & .396 & 2.5 \\
\hline $\begin{array}{l}\text { Satisfaction with } \\
\text { System }\end{array}$ & .302 & .889 & .037 & .340 & .735 & .751 & 1.3 \\
\hline Satisfaction with Job & .198 & 1.444 & .021 & .137 & .891 & .383 & 2.61 \\
\hline
\end{tabular}

\section{Source: SPSS Output}

None of the beta coefficients becomes statistically significant when three different dimensions of satisfaction are looked into separately, however, the beta coefficients result positive values. This result provides an indication that practitioners' level of satisfaction doesn't influence sophistication of firms in terms of adoption of different management accounting practices.

\section{Conclusions}

Attainment of SMAP by firms is driven by different contingent factors. Management accounting practices follow contingency framework as it is not mandated by law and the practices are not standardized like financial accounting. This study, based on the literature review, has identified eight contingent variables with the expectation that these variables may collectively drive the sophistication initiative of manufacturing firms. The analysis comes out with a very worrying picture that mostly all the factors except 'maturity' carry no significance in explaining the level of sophistication achieved by the firms. This finding is very important for understanding the business environment in Bangladesh. The demand for management accounting information is not that much critical to management and thus, they may not be that much serious with the sophisticated management accounting tools. Rather, accounting system is mainly designed based on the mandatory needs of the market and management accounting is embedded within traditional financial accounting and reporting system.

The significance of years in operation (age) parameter gives a new dimension to the study of sophistication in a country like Bangladesh which is struggling with a mass of first generation firms. As these firms are growing older, they are trying to perform professionally. This may be a good reason why years in operation influence the level of sophistication. Other factors which theoretically demand sophisticated management accounting systems have been proved irrelevant in Bangladesh. The country still needs more maturity on some internal and external factors as considered in this study to instill sophisticated management accounting systems.

Very interestingly, practitioners' satisfaction on the system and job has no impact on sophisticated management accounting systems which demonstrates the application of a peculiar isomorphism theory. The contextualization of isomorphism theory (DiMaggio and Powell, 1983) in management accounting practice is essentially been shaped by coercive, mimetic, or normative pressures. Institutions in a geography, location, sector or industry become more like one another because innovations are broadly diffused (DiMaggio and Powell, 1983). This study believes that mimetic isomorphism is active in Bangladesh in the field of management accounting practices. Firms usually follow others while choosing particular management accounting tools and matured firms having enough resources are in a position to afford implementing sophisticated management accounting techniques. However, for the massive diffusion of sophisticated management accounting techniques, coercive and normative isomorphisms are important. For coercive isomorphism, firms operating in a certain area should involve themselves into severe completion which leads them to implement sophisticated techniques to guide them in taking critical decision. At the same time, to encourage normative isomorphism, the role of professional accounting bodies, other regulators, researchers and academics must play strong role which seems to be nonexisted in emerging economy like Bangladesh.

\section{References}

Abdel-Kader, M. and Luther, R. (2008), 'The impact of firm characteristics on management accounting practices: A UK-based empirical analysis', The British Accounting Review, Vol. 40, No. 1, 2-27.

Abernethy, M. A., Lillis, A. M., Brownell, P. and Carter, P. (2001), 'Product diversity and costing design: Field study evidence', Management Accounting Research, Vol. 12, No. 3, 261-280.

Albu, N. and Albu, C. N. (2012), 'Factors associated with the adoption and use of management accounting techniques in developing countries: The case of Romania', Journal of International Management \& Accounting, Vol. 23, No. 3, 245276.

Al-Omiri, M. and Drury, C. (2007), 'A survey of factors influencing the choice of product costing systems in UK organizations', Management Accounting Research, Vol. 18, No. 4, 399-424.

Bjornenak, T. (1997), 'Diffusion and accounting: the case of ABC in Norway', Management Accounting Research, Vol. 8, No. 1, 3-17.

Booth, P. and Giacobbe, F. (1998), 'Predicting the adoption of activity-based costing in Australian manufacturing firms' Paper presented at the $21^{\text {st }}$ Annual Congress of the European Accounting Association, Antwerp, Belgium. April.

Brierley, J. A., Cowton, C. J. and Drury, C. (2001), 'Research into product costing practice: a European perspective', The European Accounting Review, Vol. 10, No. 2, 215-256. 
Bruns, W. J. Jr. (1987), “A field study of an attempt to change and embedded cost accounting system", Bruns, W. J. Jr. and Kaplan, R. S. (Eds.), Accounting and Management: Field Study Perspectives, Harvard Business School Press, 97118

Chenhall, R. H. (2003), 'Management Control Systems Design within its Organizational Context: Findings from Contingency-Based Research and Direction for the Future', Accounting, Organizations and Society, Vol. 28, No. 2-3, 127168.

Clarke, P. J., Thorley Hill, N. and Stevens, K. (1999), 'Activity-based costing in Ireland: Barriers to, and opportunities for change', Critical Perspectives in Accounting, Vol. 10, No. 4, 443468

Cooper, R. and Kaplan, R. S. (1992), 'Activity-based systems: measuring the costs of resource usage', Accounting Horizon, Vol. 6, No. 3, 1-13.

Cooper R. (1988), 'The Rise of Activity-Based CostingPart Two: When Do I Need an Activity- Based Cost System?' Journal of Cost Management, Fall, 41-48.

Davila, T. (2005), 'An exploratory study on the emergence of management control systems: formalizing human resources in small growing firms', Accounting, Organizations and Society, Vol. 30, No. 1, 223-48.

DiMaggio, P. J. and Powell, W. W. (1983), 'The Iron Cage Revisited: Institutional Isomorphism and Collective Rationality in Organizational Fields', American Sociological Review, Vol. 48, No. 2, $147-160$

Drury, C. and Tayles, M. (2005), 'Explicating the design of overhead absorption procedures in UK organizations', British Accounting Review, Vol. 37 , No. $1,47-84$.

Estrin, T. L., Kantor, J. and Albers, D. (1994), 'Is ABC suitable for your company?' Management Accounting, Vol. 75, No. 10, 40-45.

Fullerton, R. R. and McWatters, C. S. (2002), 'The role of performance measures and incentive systems in relations to the degree of JIT implementation', Accounting, Organizations and Society, Vol. 27, No. 8, 711-735.

Gosselin, M. (1997), 'The Effect of Strategy and Organizational Structure on the Adoption and Implementation of Activity-Based Costing', Accounting, Organizations and Society, Vol. 22, No. 2, 105-122.

Haldma, T. and Lääts, K. (2002), 'Contingencies influencing the management accounting practices of Estonian manufacturing companies', Management Accounting Research, Vol. 13, No. 2, 379-400.
Hannan, M. T. and Freeman, J. (1989), Organizational Ecology, Harvard University Press, Cambridge, MA.

Hoque, Z. (2008). Predicting change in management accounting and control systems: additional evidence from Australia (July 15, 2008). Social Science Research Network, available at https://ssrn.com/abstract=1160125

International Federation of Accountants (IFAC) (1998), International Management Accounting Practice Statement: Management Accounting Concepts, New York.

Ittner, C. D. and Larcker, D. F. (2001), 'Assessing empirical research in managerial accounting: a value-based management perspective', Journal of Accounting and Economics, Vol. 32, No. 13, 349-410.

Ittner, C. D. and Larcker, D. F. (2002), 'Empirical managerial accounting research: are we just describing management accounting practice?' European Accounting Review, Vol. 11, No. 4, $787-794$

Johnson, H. T. and Kaplan, R. S. (1987), Relevance Lost: The Rise and Fall of Management Accounting, Harvard Business School Press.

Jørgensen, B. and Messner, M. (2010), 'Accounting and strategizing: A case study from new product development', Accounting, Organizations and Society, Vol. 35, No. 2, 184-204.

Joshi, P. L. (2001), 'The international diffusion of new management accounting practices: the case of India', Journal of International Accounting, Auditing and Taxation, Vol. 10, No. 1, 85-109.

Kaplan, R. S. (1984), 'The evolution of management accounting', The Accounting Review, Vol. 59, No. 3, 390-418.

Khandwalla, P. N. (1977), The design of organizations, Harcourt Brace Jovanovich, New York, NY

Langfield-Smith, K. (1997), 'Management control systems and strategy: a critical review', Accounting, Organization and Society, Vol. 22, No. 2, pp. 207-232. Integration, rev. edn, Boston, MA: Harvard Business School Press.

Libby, T. and Waterhouse, J. H. (1996), 'Predicting change in management accounting systems', Journal of Management Accounting Research, Vol. 8, No. 1, 137-150.

Malmi, T. (1999), 'Activity-based costing diffusion across organizations: an exploratory empirical analysis of Finnish firms', Accounting, Organizations and Society, Vol. 24, No. 8, 649672. 
Mia, L. and Clarke, B. (1999), 'Market competition, management accounting systems and business unit performance', Management Accounting Research, Vol. 10, No. 2, 137-158.

Rieg, R. (2018), 'Tasks, interaction and role perception of management accountants: Evidence from Germany', Journal of Management Control, Vol. 29, No. 2, 183-220.

Szychta, A. (2002), 'The scope of application of management accounting methods in Polish enterprises', Management Accounting Research, Vol. 13, No. 4, 401-418.

Waweru, N. M., Hoque, Z. and Uliana, E. (2004), 'Management accounting change in South Africa Case studies from retail services', Accounting, Auditing \& Accountability Journal, Vol. 17, No. 5, 675-704.

Williams, J. J. and Seaman, A. E. (2001), 'Predicting change in management accounting systems: national culture and industry effects', Accounting, Organizations and Society, Vol. 26, No. 4-5, 443460. 